\title{
Konsentrasi dan Motilitas Spermatozoa Ayam Kampung (Gallus domesticus) dalam Pengencer Ringer Laktat yang Diberi Tambahan Minyak Buah Merah (Pandanus conoideus Lam)
}

\author{
Concentration and Motility Spermatozoa of Ayam Kampung (Gallus domesticus) in Ringer Laktat \\ Diluents Adding Red Fruit Oil (Pandanus conoideus Lam)
}

\author{
Mei Isnaeni, Faidiban O. R dan Angelina N. Tethool* \\ SubLab Fisiologi dan Reproduksi Ternak \\ Fakultas Peternakan Universitas Papua \\ Jl. Gunung Salju Amban Manokwari Papua Barat 98314
}

\section{Abstract}

Article history

Accepted: July 18, 2019;

Approved: September 15, 2019

* Corresponding author: E-mail:

angelinanovitatethool@gm ail.com

Red fruit oil is a red fruit extraction product (Pandanus conoideus Lam) containing a lot of antioxidants such as carotenoids, tocopherols as well as unsaturated fatty acids such as oleic acid, linoleic acid, linolenic acid and decanoic acid which is potential to be used as an additive for semen chicken diluents. This study aims to obtain an information about the effectiveness of adding red fruit oil as a cement diluent derived from male native chickens. The treatment consisted of $0.9 \mathrm{ml}$ ringer laktat $+0.1 \mathrm{ml}$ semen $(\mathrm{Pl})$, ringer laktat $0.98 \mathrm{ml}+0.1 \mathrm{ml}$ semen $+0.02 \mathrm{ml}$ red fruit oil $(\mathrm{P} 2)$, ringer laktat $0.96 \mathrm{ml}+0.1 \mathrm{ml}$ semen $+0.04 \mathrm{ml}$ red fruit oil $(\mathrm{P} 3)$, ringer laktat $0.94 \mathrm{ml}+0.1 \mathrm{ml}$ cement $+0.06 \mathrm{ml}$ red fruit oil $(\mathrm{P} 4)$.

The results showed the sperm motility ranged from $48.17 \pm 7.86 \%$ to $84.67 \pm 2.42 \%$. Treatment $\mathrm{P} 1$ and $\mathrm{P} 2$ have a very significant difference $(\mathrm{P}$ $<0.01$ ) on motility to P3 and P4. However, treatment P1 has similar result on motility from $\mathrm{P} 2(\mathrm{P}>0.05)$. The spermatozoa concentration ranged from $1,600 \times 10^{6}$ cells $/ \mathrm{ml}$ to $2,200 \times 10^{6}$ cells $/ \mathrm{ml}$. The spermatozoa concentration of treatment $\mathrm{P} 1$ and $\mathrm{P} 2$ chickens did not show any significant differences $(\mathrm{P}>0.05)$, nor did among treatments $\mathrm{P} 2, \mathrm{P} 3$ and $\mathrm{P} 4$. However, treatment $\mathrm{P} 1$ has a significant difference on spermatozoa concentration with $\mathrm{P} 3$ and $\mathrm{P} 4$. $(\mathrm{P}<0.05)$. It can be concluded that the addition of red fruit oil in lactated ringer diluent can be used as an additive for semen diluents because it is able to maintain the concentration. In addition, adding of red fruit oil up to concentrations of more than $2 \%$ tend to reduce sperm motility.

Keywords: Concentration, Motility, Spermatozoa and Red fruit oil

\section{Pendahuluan}

Pengenceran semen sangat dibutuhkan untuk mempertahankan kualitas spermatozoa pada jangka waktu tertentu dalam pelaksanaan inseminasi buatan. Plasma darah dan air susu telah digunakan sebagai pengencer semen ayam tetapi belum memberikan hasil dan kemudian berkembang dengan menggunakan kuning telur dan air susu sapi (Toelihere, 1993). Selain untuk mempertahankan kualitas spermatozoa, pengenceran semen ayam juga dimaksudkan untuk memperbanyak volume semen setelah diejakulasikan, karena telah diketahui bahwa volume ejakulat ayam sangat sedikit tetapi memiliki konsentrasi spermatozoa yang tinggi yaitu $3000-7000 \times 10^{6}$ $\mathrm{sel} / \mathrm{ml}$ (Hafez, 2000).

Saat ini sudah banyak digunakan pengencer seperti ringer laktat, $\mathrm{NaCl}$ fisiologis, dekstrosa dengan berbagai macam 
bahan additive seperti orange jus (Al-Daraji, 2012b), jus buah delima (Al-Daraji, 2015) dan jus tomat (Al-daraji, 2014). Al-Daraji (2012a) dan Khaeruddin et al. (2015) juga telah memperkenalkan minyak zaitun, dan ekstrak bawang putih (Al-Daraji, 2013) sebagai bahan additive pengencer semen ayam. Al-Daraji (2012c) menjelaskan bahwa kandungan antioksidan dalam bahan additive tersebut mampu mempertahankan kualitas spermatozoa ayam yang mengandung asam lemak tak jenuh yang mudah rusak karena kontak langsung dengan udara ketika semen diejakulasikan. Funahashi dan Sano (2005) menyatakan bahwa, peroksidasi lipid selama masa penyimpanan merupakan faktor yang sangat merusak karena tingginya asam lemak tak jenuh dan rendahnya kandungan antioksidan pada spermatozoa. Hal ini sejalan dengan pendapat Wirahadikusumah (1985) bahwa untuk mengendalikan dan mengurangi peroksidasi lipid, diperlukan antioksidan.

Minyak buah merah adalah produk ekstraksi buah merah (Pandanus conoideus Lam) yang menurut Budi dan Paimin (2004) mengandung cukup banyak antioksidan seperti, karotenoid (12.000ppm), tokoferol (11.000ppm) juga asam lemak tak jenuh seperti asam oleat, asam linoleat, asam linolenat dan asam dekanoat sehingga potensial untuk digunakan sebagai bahan additive pada pengencer semen ayam. Penggunaan minyak zaitun dan ekstrak bawang putih dapat meningkatkan motilitas massa, motilitas individu spermatozoa, viabilitas dan menurunkan abnormalitas spermatozoa (Al-Daraji, 2012a; Al-Daraji, 2013; Khaeruddin et al., 2015).

Pengenceran dan penyimpanan semen ayam sering mengalami kerusakan, karena adanya proses respirasi didalam mitokondria sel spermatozoa yang menghasilkan radikal bebas (Blesbois et al., 2005; Partyka et al., 2007; Chabory et al., 2010; Gunawan et al., 2012;). Radikal bebas yang dihasilkan sangat merusak bagi keberlangsungan hidup sel spermatozoa karena memiliki sifat sangat reaktif dalam memperoleh elektron. Radikal bebas ini menyerang dan mengambil elektron dari asam lemak tak jenuh yang merupakan penyusun fosfolipid membran plasma sel. Dengan demikian proses ini harus dicegah agar tidak terjadi reaksi otokatalitik yang berakibat merusak seluruh fosfolipida membran plasma sel spermatozoa (Funahashi dan Sano, 2005; Long dan Kramer, 2003; Rizal, 2005).

Peroksidasi lipid dapat diatasi dengan cara melindungi membran sel spermatozoa dengan antioksidan (Wirahadikusumah, 1985; AlDaraji, 2012a; Khaeruddin et al., 2015). Tokoferol merupakan antioksidan kuat yang secara umum mampu mencegah radikal bebas dan aktivasi endonuklease. Tokoferol juga, karena bersifat larut dalam lemak mampu melindungi membran sel dari peroksidasi lipid. Budi dan Paimin (2004) juga melaporkan bahwa minyak buah merah mengandung senyawa antioksidan seperti karotenoid dan tokoferol serta asam lemak tak jenuh yang terdiri dari asam oleat, asam linoleat, asam linolenat, dan asam dekanoat, sehingga potensial digunakan sebagai bahan additive pengencer semen ayam kampung. Penelitian ini bertujuan untuk mendapatkan informasi tentang efektivitas penambahan minyak buah merah sebagai pengencer semen yang berasal dari ayam kampung jantan.

\section{Materi dan Metode}

Penelitian ini menggunakan ayam kampung jantan berumur 8 bulan dengan berat badan 1800 - 2100gram dan dirancang dengan menggunakan Rancangan Acak Lengkap (RAL), dengan 4 taraf perlakuan dan 6 kali ulangan sehingga diperoleh 24 satuan percobaan. Perlakuan yang diberikan terdiri dari:

$\mathrm{P}_{1}$ : Ringer laktat $0,9 \mathrm{ml}+0,1 \mathrm{ml}$ semen (Kontrol)

$\mathrm{P}_{2}$ : $\quad$ Ringer laktat $0,98 \mathrm{ml}+0,1 \mathrm{ml}$ semen + $0,02 \mathrm{ml}$ minyak buah merah

P3 : Ringer laktat $0,96 \mathrm{ml}+0,1 \mathrm{ml}$ semen + $0,04 \mathrm{ml}$ minyak buah merah

P4 : Ringer laktat $0,94 \mathrm{ml}+0,1 \mathrm{ml}$ semen + $0,06 \mathrm{ml}$ minyak buah merah

Penampungan semen dilakukan dengan menggunakan metode masase atau pengurutan pada bagian dorsal atau punggung ayam jantan hingga pangkal ekor, kemudian semen ditampung menggunakan tabung eppendorf berukuran dua mililiter. Bagian bibir kloaka dibersihkan dengan menggunakan kapas yang telah dibasahi dengan larutan $\mathrm{NaCl}$ fisiologis 
$0,9 \%$ sebelum penampungan. Penambahan sari buah merah berfungsi sebagai antioksidan yang mencegah kerusakan oksidasi. Setelah pemberian sari buah merah spermatozoa yang diencerkan langsung dievaluasi tanpa adanya waktu penyimpanan.

Penentuan motilitas dilakukan dengan cara meneteskan satu tetes semen pada object glass lalu ditutup dengan cover glass kemudian diamati di bawah mikroskop. Pengamatan dilakukan pada gerakan spermatozoa yang bergerak progresif pada lima lapang pandang yang berbeda (Indrawati et al., 2013).

Penghitungan konsentrasi spermatozoa dengan menggunakan Neubauer chamber. Semen diteteskan ke dalam kamar hitung pada Neubauer chamber yang telah ditutup dengan cover glass. Penghitungan sel spermatozoa dilakukan pada lima kamar hitung. Jumlah sel spermatozoa yang telah dihitung pada lima kamar kemudian dikali dengan $10^{6} \mathrm{sel} / \mathrm{ml}$ (Yudi et al., 2007).

Data yang diperoleh dianalisis dengan one way annova (sidik ragam menurut rancangan acak lengkap) menggunakan software statistik minitab® versi.17 (Minitab, 2016), apabila hasil memberikan pengaruh nyata $(\mathrm{P}<0,05)$ maka dilanjutkan dengan uji BNJ (Beda Nyata Jujur).

\section{Hasil dan Pembahasan}

Motilitas spermatozoa adalah daya gerak progresif spermatozoa. Daya gerak progresif spermatozoa sangat penting karena tanpa motilitas yang baik, spermatozoa tidak akan berhasil membuahi sel telur (Toelihere, 1993).

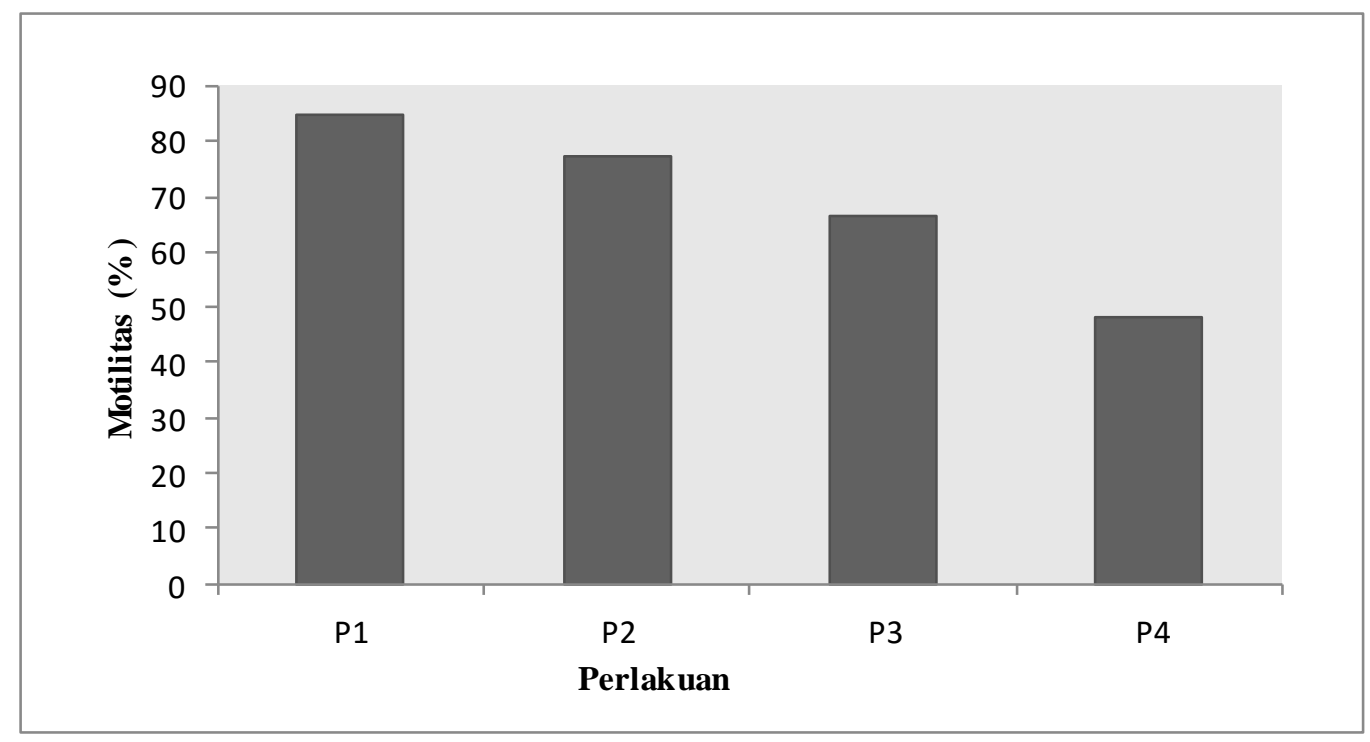

Gambar 1. Motilitas Spermatozoa Ayam Kampung yang Diencerkan dengan Ringer Laktat dan Minyak Buah Merah

Motilitas spermatozoa hasil penelitian berkisar antara 48,17 $\pm 7,86-84,67 \pm 2,42 \%$ (Gambar 2). Motilitas seperti ini sangat mendukung sel spermatozoa untuk mencapai sel telur di dalam saluran reproduksi ayam betina dalam waktu yang singkat dan memungkinkan terjadinya fertilisasi yang berhasil. Menurut Hafez (2000) motilitas individu spermatozoa pada semen unggas yang normal berkisar antara 60-80\%. Dengan demikian motilitas spermatozoa yang ditemukan dalam penelitian ini masih dapat dikatakan berada pada kisaran yang kurang lebih normal.
Hasil analisis sidik ragam terhadap motilitas spermatozoa yang disimpan pada suhu ruangan $\left(27-29^{\circ} \mathrm{C}\right)$ selama 15 menit menunjukkan bahwa kontrol (P1) dan pengencer dengan penambahan minyak buah merah sebanyak $2 \% \quad(\mathrm{P} 2)$ menunjukkan perbedaan yang sangat nyata $(\mathrm{P}<0,01)$ dibanding pengencer dengan penambahan minyak buah merah sebanyak $4 \%$ (P3) dan 6\% (P4). Sementara P1 tidak berbeda dengan P2 $(\mathrm{P}>0,05)$.

Hasil penelitian ini menunjukkan bahwa penambahan minyak buah merah sampai taraf $2 \%$ kedalam pengencer akan memberikan hasil 
yang lebih baik jika dibandingkan penambahan minyak buah merah lebih dari $2 \%$, sebab semakin tinggi taraf minyak buah merah yang ditambahkan kedalam pengencer akan menurunkan motilitas spermatozoa ayam kampung. Hasil penelitian ini tidak sejalan dengan hasil yang dilaporkan Al-Daraji (2012a) yang menambahkan minyak zaitun kedalam pengencer semen ayam dan melaporkan bahwa konsentrasi minyak zaitun yang ditingkatkan dapat meningkatkan motilitas spermatozoa. Hal ini dapat diterima karena selain menggunakan bahan pengencer yang berbeda, minyak yang digunakanpun mungkin memiliki kualitas dan kandungan antioksidan yang lebih baik dibanding kualitas minyak buah merah yang digunakan pada penelitian ini selain teknik penanganan perlakuan percobaan.

Faktor lain yang mungkin mengakibatkan menurunnya motilitas spermatozoa ayam pada penelitian dengan menambahkan minyak buah merah ini adalah kandungan minyak yang cukup tinggi pada ekstrak buah merah yang mungkin ikut menghambat pergerakan spermatozoa. Menurut Khaeruddin et al.
(2015) angka motilitas spermatozoa yang diencerkan dengan tambahan (MZEV) yang lebih banyak akan berkurang sebab pergerakannya sangat dipengaruhi oleh banyaknya molekul - molekul MZEV yang menghambat pergerakannya. Hal yang sama dilaporkan Solihati (2008) bahwa pemberian santan sebagai pengencer semen dapat menghambat pergerakan spermatozoa karena santan mengandung lemak.

Penambahan dosis minyak buah merah mengakibatkan terjadinya penurunan motilitas, namun motilitas spermatozoa ayam kampung yang diperoleh masih berada pada kisaran normal dan layak digunakan pada IB. Menurut Toelihere (1993), semen untuk IB tidak layak digunakan ketika motilitas spermatozoanya kurang dari $40 \%$.

Konsentrasi spermatozoa merupakan banyaknya spermatozoa yang terdapat dalam satu ejakulat setiap kali penampungan semen dilakukan. Konsentrasi spermatozoa dalam satu ejakulat sangat dipengaruhi oleh genotipe seperti bangsa ayam (Graham, 1978), strain (Peters et al., 2008) dan line (Murugesan et al., 2013).

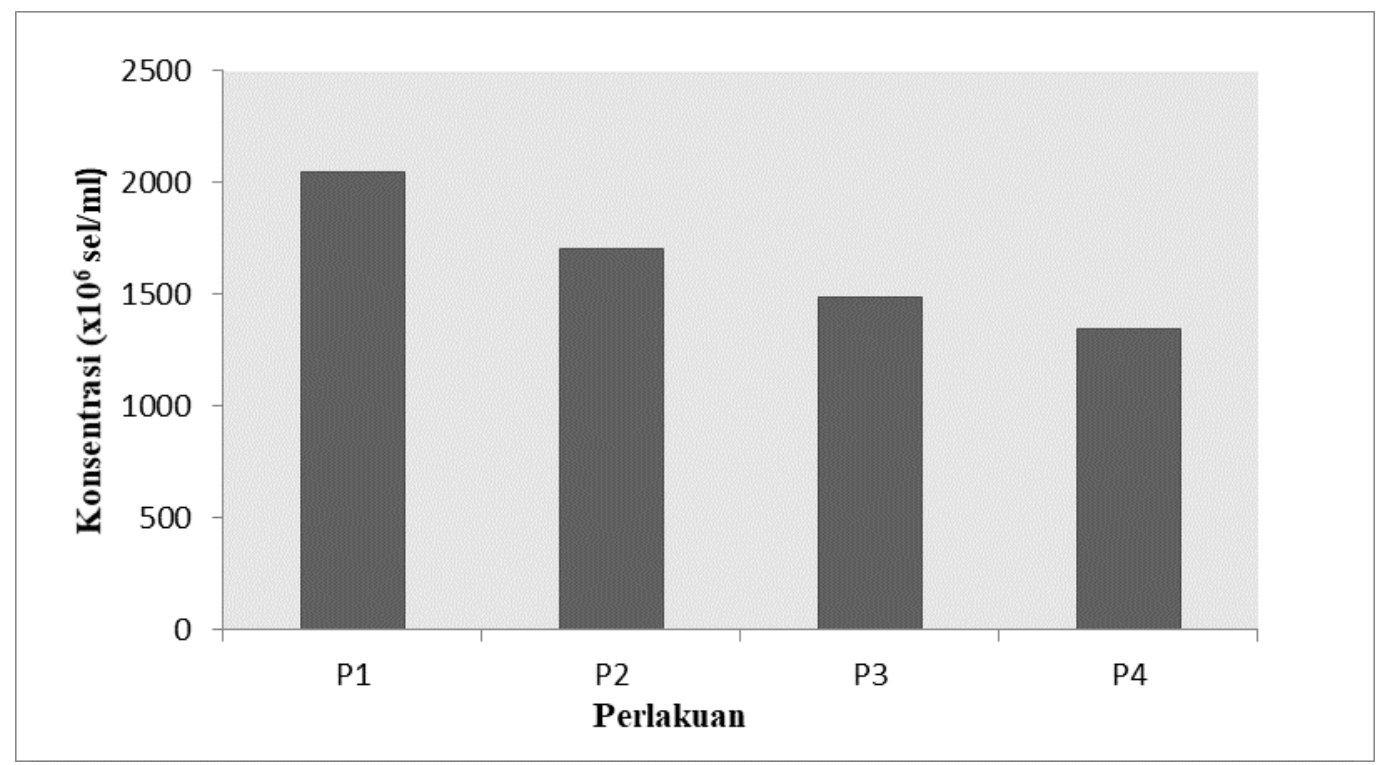

Gambar 2. Rata-rata Konsentrasi Spermatozoa Ayam Kampung yang Diencerkan dengan Ringer Laktat dan Minyak Buah Merah

Hasil analisis sidik ragam terhadap konsentrasi spermatozoa ayam kampung yang diencerkan dengan $\mathrm{P} 1$ dan $\mathrm{P} 2$ tidak menunjukkan perbedaan yang nyata $(\mathrm{P}>0,05)$, demikian pula dengan $\mathrm{P} 2, \mathrm{P} 3$ dan $\mathrm{P} 4$ tidak menunjukkan perbedaan $(\mathrm{P}>0,05)$. Namun demikian, P1 menunjukkan perbedaan yang nyata dengan $\mathrm{P} 3$ dan $\mathrm{P} 4(\mathrm{P}<0,05)$.

Hasil penelitian ini menunjukkan bahwa konsentrasi spermatozoa ayam kampung yang diencerkan dengan penambahan minyak buah merah sampai taraf $2 \%$ masih menunjukkan konsentrasi yang kurang lebih sama dengan 
P1, tetapi konsentrasi spermatozoa menjadi berkurang ketika taraf minyak buah merah lebih dari $2 \%$. Hasil penelitian ini tidak seperti yang diharapkan sebab, semakin banyak minyak buah merah yang ditambahkan viskositas pengencer akan semakin tinggi dan berakibat pada menempelnya sel-sel spermatozoa pada dinding tabung ependorf dan ketika dipindahkan ke dalam Neubauer chamber sebagian lagi akan menempel pada erytrosyt pipet sehingga berdampak pada rendahnya konsentrasi spermatozoa pada pengencer dengan minyak buah merah yang lebih banyak. Walaupun demikian, hasil penelitian ini masih lebih baik dari laporan Lubis (2011) dan Sopiyana et al. (2006) dengan konsentrasi spermatozoa $1.600 \times 10^{6}$ $\mathrm{sel} / \mathrm{ml}$ dan $1.335 \times 10^{6} \mathrm{sel} / \mathrm{ml}$. Selain faktor yang telah dijelaskan di atas, perbedaan hasil penelitian yang diperoleh ini mungkin juga disebabkan perbedaan jenis ayam yang digunakan pakan dan juga umur ayam, seperti yang dikemukakan oleh Toelihere (1993) bahwa faktor-faktor bangsa, pakan, umur dan faktor lingkungan turut mempengaruhi konsentrasi spermatozoa yang dihasilkan.

Gambar 2. menunjukkan pengaruh konsentrasi minyak buah merah dalam larutan ringer laktat terhadap konsentrasi spermatozoa ayam kampung. Rata-rata konsentrasi spermatozoa ayam kampung yang telah diencerkan pada penelitian ini adalah antara $1.600 \times 10^{6} \mathrm{sel} / \mathrm{ml}$ sampai dengan $2.200 \times 10^{6}$ $\mathrm{sel} / \mathrm{ml}$. Konsentrasi spermatozoa sejumlah ini sangat mendukung untuk suatu fertilisasi yang berhasil karena menurut laporan Bramwell et al. (1995), ayam yang diinseminasi dengan sperma sebanyak 100, 50 dan $25 \times 10^{6} \mathrm{sel} / \mathrm{ml}$ memberikan fertilitas sebesar 95,8\%, 92,4\% dan 83,3\%. Dengan demikian konsentrasi spermatozoa yang ditemukan dalam penelitian ini masih sangat jauh lebih banyak dan dipercaya mampu membuahi ayam betina yang di IB dengan keberhasilan yang memadai.

\section{Kesimpulan}

Penambahan minyak buah merah dalam pengencer ringer laktat memberikan pengaruh hingga konsentrasi 2\%. Apabila dosis yang diberikan melebihi $2 \%$ akan memberikan randahnya motilitas dan konsentrasi spermatozoa.

\section{Daftar Pustaka}

Al-Daraji, H. J. 2012a. Adding olive oil to rooster semen diluents for improving semen quality and storage ability during liquid. International Science Index, Animal and Veterinary Sciences, 6(10):862-867.

Al-Daraji, H. J. 2012b. Effect of diluent supplementation with different levels of orange juice on semen quality during liquid storage of roosters' semen. International Journal Veteriner Science, 1(1): 5-9.

Al-Daraji, H. J. 2012c. Red wine as a diluent supplement for counteract the deleterious effects of lipid peroxidation during liquid storage of aged roosters semen. Nature and Science, 10(9):64-70.

Al-Daraji, H. J. 2013. Effect of diluent supplementation with garlic extract on semen quality of cocks during liquid storage. International Journal of Pharma and Bio Scienses, 4(3): 1260 - 1270.

Al-Daraji, H. J. 2014. Effect of diluent supplementation with tomato juice on semen quality and storage ability of roosters semen during liquid storage. International Journal of Biology, Pharmacy and Allied sciences, 1(7):918926.

Al-Daraji, H. J. 2015. Effects of pomegranate juice as diluent supplementation on sperm quality during liquid storage of chicken semen. International Journal of Chemistry and Pharmaeutical sciences, 2(1):606-611.

Blesbois, E., Grasseau, I. and Hermier, D. 1999. Changes in lipid content of fowl spermatozoa after liquid storage at 2 to $5^{0} \mathrm{C}$. Theriogenology, 52:325-334.

Budi, M. dan Paimin, F. R. 2004. Sari Buah Merah Sebagai Obat Multi Khasiat. Jakarta: Penebar swadaya.

Bramwell, K. R., Marks, H. L. and Howarth, B. 1995. Physiology and reproduction quantitative determination of spermatozoa penetration of the perivitelline layer of the hen's ovum as assessed on oviposited eggs. Poultry Science, 74 : 1875-1883.

Chabory, E., Damon, C., Lenoir, A., HenryBerger, J., Vernet, P., Cadet, R., et al. 
2010. Mammalian glutathione peroxidases control acquisition and maintenance of spermatozoa integrity. Journal Animal sciences, 88: 1321-1331.

Funahashi, H. and Sano, T., 2005. Selected antioxidants improve the function of extended boar semen stored at $10^{\circ} \mathrm{C}$. Theriogenology, 63(6): 1605-1616.

Graham, E. F. 1978. Fundamentals of the Preservation of Spermatozoa. In The Integrity of Frozen Spermatozoa. National Academy of Sciences, Washington D.C. p228.

Gunawan, I., Laksmi, D. N. D. I. dan Trilaksana, I. G. N. B. 2012. Efektivitas penambahan $\beta$-karoten dan glutathion pada bahan pengencer terhadap motilitas dan daya hidup spermatozoa pada semen beku sapi. Indonesia Medicus Veterinus, 1(3) : $385-393$.

Hafez, E. S. E. 2000. Reproduction in Farm Animals. (7 th ed) Kiawah island, south Carolina, USA.

Indrawati, D., Bebas, W., dan Trilaksana, I. G. N. B. 2013. Motilitas dan daya hidup spermatozoa ayam kampung dengan penambahan astaxanthin pada suhu $3-5^{0} \mathrm{C}$. Indonesia Medicus Veterinus, 2(4) : 445 452.

Khaeruddin., Sumantri, C., Darwati, S. dan Arifiantini, R. I. 2015. Penggunaan minyak zaitun ekstrak virgin ke dalam bahan pengencer semen terhadap kualitas spermatozoa ayam lokal. Jurnal Ilmu Produksi dan Teknologi Hasil Peternakan, 3(1) : 46-51.

Long, J. A. and Kramer, M. 2003. Effect of vitamin $\mathrm{E}$ on lipid peroxidation and fertility after artificial insemination with liquid-stored turkey semen. Poultry Sciences, (82) : 1802-1807.

Lubis, T. M. 2011. Motilitas spermatozoa ayam kampung dalam pengencer air kelapa, $\mathrm{NaCl}$ fisiologis dan air kelapa$\mathrm{NaCl}$ fisiologis pada $25-29^{\circ} \mathrm{C}$. Agripet, 11(2) : 45-50.
Murugesan, S., Matam, N., Kulkarni, R., Bhattacharya, T. K. and Chatterjee, R. N. 2013 Semen quality in white leghorn chicken selected for egg production traits turk. J. Vet. Anim. Sci, 37: 747-749.

Partyka, A., Jerysz, A., Pokorny, P. 2007. Lipid peroxidation in fresh and stored semen of green-legged partridge. Electronic Journal of Polish Agricultural Universities, 10(2):08.fromhttp://www.ejpa u.media.pl/volume10/issue2/art-08.html

Peters, S. O., Shoyebo, O. D., Ilori, B. M., Ozoje, M. O., Ikeobi, C. O. N. Et al. 2008. Semen quality traits of seven strain of chickens raised in the humid tropics. Int. J. Poult. Sci, 7: 949-953.

Rizal, M. dan Herdis. 2005. Daya hidup spermatozoa epididimis domba garut yang dikriopreservasi menggunakan modifikasi pengencer tris. Hayati, 12(2) : 61-66.

Solihati, N. 2008. Studi terhadap kualitas dan daya tahan hidup spermatozoa cauda epididimis domba garut menggunakan berbagai jenis pengencer. Seminar Nasional Teknologi Peternakan dan Veteriner (pp.401-408). Bandung: Fakultas Peternakan Universitas Padjadjaran.

Sopiyana, S., Iskandar, S., Susanti, T. dan Yogaswara, D. 2006. Pengaruh krioprotektan dma, dmf dan glycerol pada proses pembekuan semen ayam kampung. Seminar Nasional Teknologi Peternakan dan Veteriner (pp.702-708). Bogor : Balai Penelitian Ternak.

Toelihere, M. R. 1993. Inseminasi Buatan Pada Ternak. Bandung: Angkasa.

Wirahadikusumah, M. 1985. Biokimia : Metabolism Energy, Karbohidrat and Lipid. Bandung: ITB.

Yudi., Arifiantini, I., Purwantara, B. dan Yusuf, T. L. 2007. Karakteristik semen segar dan kualitas semen cair kuda dalam pengencer dimitropoulos yang disuplementasi dengan fruktosa, trehalosa dan rafinosa. Media Peternakan, 30(3) : 163-172 